\title{
Full mouth rehabilitation in patient with deep bite, inter-dental arch discrepancy and loss of vertical dimension: a case report
}

\author{
Han-Sol Song, Ye-Jin Lee, Kyung-Ho Ko, Yoon-Hyuk Huh, Lee-La Cho, Chan-Jin Park* \\ Department of Prosthodontics \& Research Institute of Oral Science, College of Dentistry, Gangneung-Wonju National University, \\ Gangneung, Republic of Korea
}

Loss of posterior bite support might cause unstable occlusal relationship and when the mandible slides forward in the centric or habitual occlusion, excessive load is applied to the anterior region followed by causing the occlusal plane to collapse or leading to a decrease in occlusal vertical dimension. In addition, disorder of temporomandibular joint function may occur. The inter-dental arch discrepancy causes a mismatch in the vertical and horizontal overlap of the anterior and posterior regions. The deep bite in the anterior region and the scissor bite in the posterior region cause unstable occlusal contact and insufficient occlusal contact area. This report was to rehabilitate a patient with above-mentioned complex problems. Physiologic adaptation to increased vertical dimension and new occlusal plane were evaluated using provisional prostheses, and definitive prostheses was fabricated using cross-mounting technique. Stable occlusion, harmonious teeth overlap and adequate occlusal plane were established, so functionally and aesthetically satisfactory results are obtained. (J Dent Rehabil Appl Sci 2021;37(3):157-70)

Key words: deep bite; inter-dental arch discrepancy; occlusal vertical dimension; full mouth rehabilitation

\begin{abstract}
서론
상하악의 불안정한 교합관계는 구치부 지지 상실(posterior bite collapse)과 같은 치아상실에 따라 인접치아의 위치변화 뿐만 아니라 대합치열의 변화와 전방치열에도 영향을 미친다. ${ }^{1-3}$ 이러한 경우 중심교합위나 습관적 폐구 위에서 하악이 전방으로 활주하면 전치부에 과도한 하중 이 가해져 전치부의 순측경사이동(flaring)이 발생할 수 있고, 하악 전치도 보상성으로 정출하거나 flaring 현상 이 발생하고 교합평면이 불규칙해지거나 심한 만곡을 갖 게 되어 교합수직고경(occlusal vertical dimension)의 감 소와 악관절 기능 장애까지 나타낼 수 있다. Ramfjord와 $\mathrm{Ash}^{2}$ 는 구치부 상실로 인한 중심위 활주(slide in centric) 가 커져 전치부에 하중이 증가하고 저작습관과 근활성

*Correspondence to: Chan-Jin Park Department of Prosthodontics \& Research Institute of Oral Science, College of Dentistry, Gangneung-Wonju National University, Jukheongil 7, Gangneung, Gangwondo, 25457, Republic of Korea Tel: +82-33-640-3153, Fax: + 82-33-640-3103, E-mail: doctorcj@gwnu.ac.kr Received: July 9, 2021/Last Revision: August 9, 2021/Accepted: August 9, 2021
\end{abstract}

(muscle tonicity)의 변화에 의해 교합관계의 변화가 생긴 다고 하였다. 구치부 지지상실은 치아 자체의 상실뿐 아 니라 치간공극 증가, 치아우식, 잘못된 수복물, 잘못된 교합치료, 치아마모와 부정교합 등이 원인이 될 수 있다. ${ }^{1}$

과개교합(deep bite)은 하악이 최대교두감합위 또는 중심교합위에 있을 때 상하악 절치 절단 간의 수직 거리 가 정상보다 과도한 경우를 말한다. ${ }^{3-5}$ 정상적인 수직피 개량의 평균치는 하악의 최대감합위에서 상악 절치에 의 해 하악 절치 $1 / 3$ 정도가 피개된다. ${ }^{6}$ 다양한 요인에 의해 전치부의 수직피개는 달라질 수 있으며, 수직피개량이 크 다고 해서 그 자체로 치열이 병적인 상태에 있다고 할 수 없다. ${ }^{7}$ Dawson은 과개교합이 그 자체가 문제되는 것은 아니며 전치부의 안정된 유지 접촉이 없을 경우에만 문제 가 된다고 주장하였다. ${ }^{8}$ 따라서 과개교합 환자를 진단할

Copyright@ 2021 The Korean Academy of Stomatognathic Function and Occlusion. (c) It is identical to Creative Commons Non-Commercial License. 
때, 현재의 교합접촉이 얼마나 안정적인가를 세심하게 평 가해야 하며, 하악 전치가 상악 전체에 안정된 교합 접촉 을 하는지를 판단하는 것에서부터 시작해야 하고, 반드 시 중심위로 장착된 진단모형상에서 분석이 이루어져야 한다. ${ }^{8}$ 만약 전치부의 교합접촉이 안정적으로 하악 전치 의 정출을 방지할 수 있는 정지접촉이 아니라면, 하악 전 치는 계속적인 마모와 정출을 반복하게 될 것이다. ${ }^{8}$

치열궁 크기의 부조화는 상하악 기저골 자체는 정상 이지만 상하악 치열궁의 크기와 형태의 부조화가 원인이 되어 구치부의 전후방 및 측방관계와 전치부의 수직, 수 평관계 및 정중선 편위 등의 3 차원적으로 복합적인 문제 가 발생하게 된다. ${ }^{9}$ 치열궁 크기 부조화로 나타나는 전 치부의 과개교합과 구치부의 가위교합은 불안정한 교합 접촉과 충분하지 못한 교합접촉면적을 야기하며, 구치 부 교합지지 상실로 인해 과도한 정출이 발생하기도 한 다. ${ }^{7,810}$ Tomonari 등 ${ }^{11}$ 은 구치부 가위교합을 보이는 경우 가 그렇지 않은 경우에 비하여 저작 시 하악의 작은 측방 운동과 느리고 수직적인 저작양상(chopping pattern)을 보이며, 저작효율의 감소가 발생한다고 보고하였다.

앞서 언급한 구치부지지상실, 증가된 수직 및 수평피 개를 보이는 환자의 경우 구치부 지지 회복과 더불어 적 절한 수직수평관계를 가지는 안정적인 교합의 형성이 필 수적이다. ${ }^{4}$ 본 증례는 불안정한 교합접촉 및 교합평면의 붕괴로 인하여 치열궁 크기의 부조화를 보이고 전치부의 과개교합과 구치부의 가위교합으로 환자의 전악보철수 복을 진행하여 수직고경을 적절하게 회복함으로써 조화 로운 수평피개와 교합평면을 재설정하여 교합접촉면적 을 개선하고 안정적인 교합을 형성하였기에 이를 보고하 고자 한다.

\section{증례 보고}

64세 남성이 파절된 전치부의 처치를 주소로 내원하 였다. 고혈압으로 인해 투약 중이었고, 특이할 만한 치과 적 병력은 없었으나 파노라마방사선사진 검사에서 전반 적인 골소실을 동반한 치주염과 다수의 파절된 치아가 관찰되었다(Fig. 1). 구외 안모평가 시 발달된 교근과 작 은 하악각으로 강한 저작력이 예상되고 상순의 지지상실 을 보였다. 구내 검사 시 전치부 과개교합 상태, 대합치가 상실된 치아의 정출과 상악 전치부 치경부에 하악절치 에 의한 압흔이 관찰되었으며 역전된 윌슨만곡(Curve of Willson)의 양상과 함께 교합평면이 불균일했다(Fig. 2AC). 비가역성 하이드로콜로이드(Aroma Fine Plus, GC Co., Tokyo, Japan)를 이용하여 예비인상을 채득하여 제 작한 진단모형 분석 시 전치부와 구치부에서 큰 수평피 개가 관찰되었다.

보철 전 처치로 치주질환의 처치와 함께 동통이 있는 치근상태의 상악 전치부와 상하악 구치부를 발거하고 치 유기간이 경과한 후에(Fig. 2D-F), 진단과 치료계획 수립 을 위해 예비인상을 다시 채득하여 진단모형을 제작하 고 중심위에서 실리콘 교합인기재(I-Sil ${ }^{\mathrm{TM}} \mathrm{Bite}$, Spident, Incheon, South Korea)를 이용하여 악간관계기록 채득 및 안궁이전을 시행하여 반조절성 교합기에 중심위 악간 관계기록을 이용하여 부착하였다(Fig. 3).

발치 전 진단모형 분석에서 상악 중심와 간 거리와, 하 악 기능교두 간 거리를 비교했을 때, 대구치에서는 두드 러지지 않으나 소구치에서 수평적으로 치열궁 크기의 차 이를 보이면서 상악은 사각형, 그리고 하악은 V자형 악 궁으로 형태적 차이를 보였다. 발치 후 진단모형 분석에

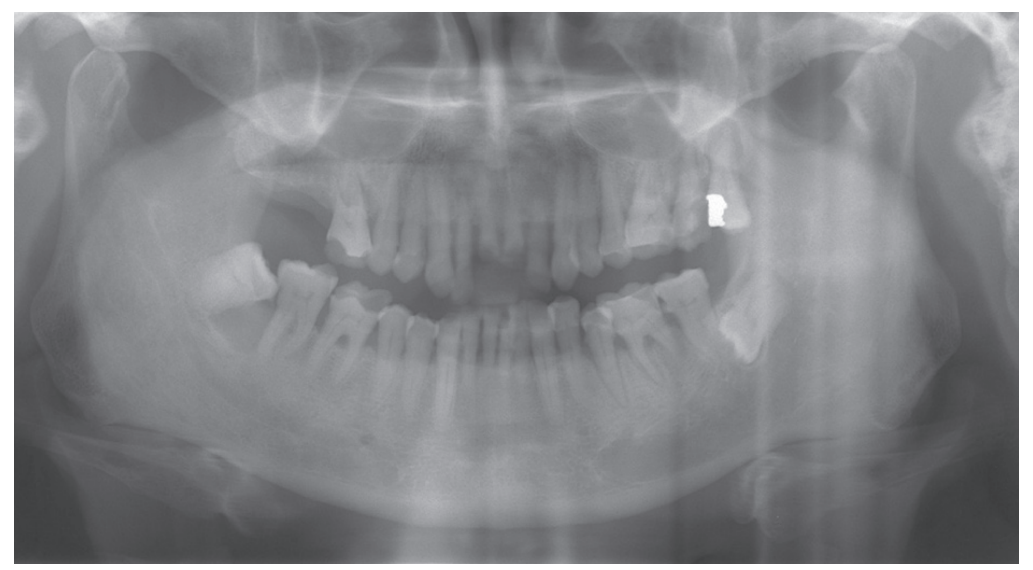

Fig. 1. Initial panoramic radiograph. 

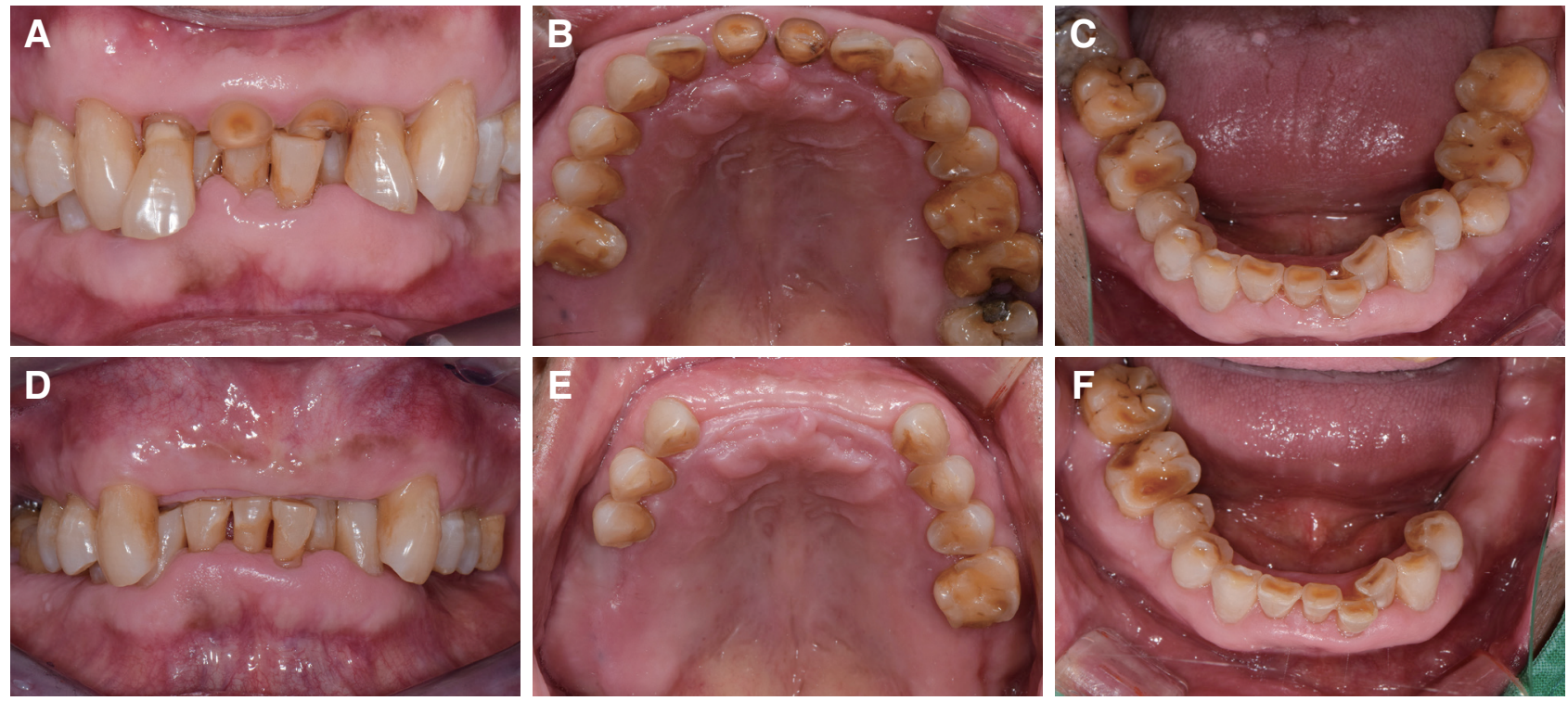

Fig. 2. Intraoral photograph. (A- C) At first visit, (D- F) At re-visit after extraction of teeth.
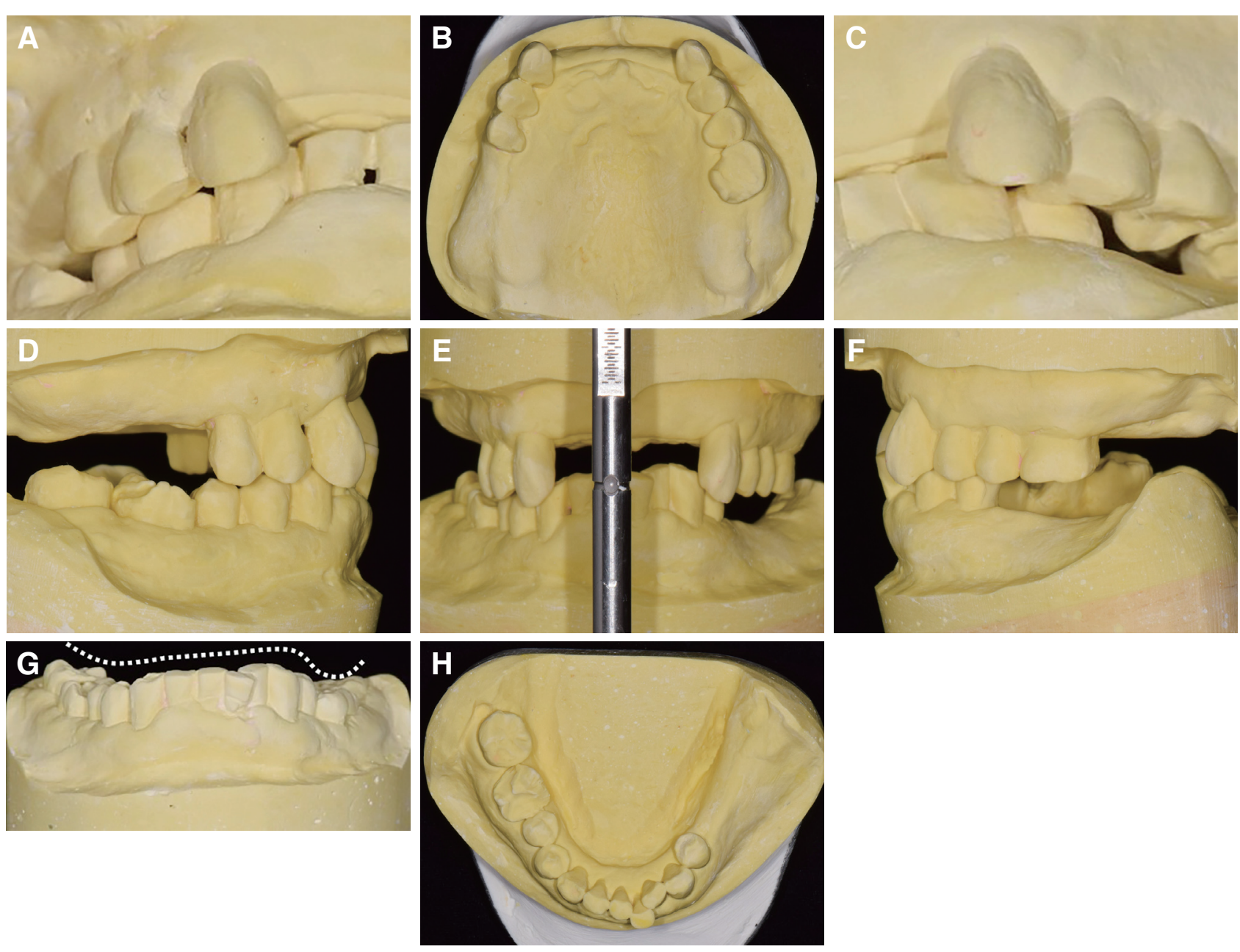

Fig. 3. Diagnostic cast analysis on semi-adjustable articulator at re-visit after extraction of teeth. (A) Right unstable occlusal contact, (B) Maxillary occlusal view, (C) Left scissor bite, (D) Right lateral view, (E) Frontal view, (F) Left lateral view, (G) Irregular occlusal plane, (H) Mandibular occlusal view. 
서 좌측은 가위교합(scissor bite)이고 우측은 상악 잔존 치 마모와 함께 사면에서 교합접촉이 형성되어 불안정한 교합접촉을 보였다(Fig. 3A, 3C). 또한 대구치 교합의 상 실 상태로 Eichner's index category B-II로 분류되고, ${ }^{12}$ Willis법 ${ }^{13}$ 을 이용한 안모분석비율과 교합안정거리(interocclusal rest distance) 측정 시 수직고경이 감소되어(Fig. 4), Turner와 Missirlian이 교합수직고경과 관련하여 분 류한 세 가지 분류 중 과도한 치아마모와 함께 교합수직 고경의 상실이 동반된 경우인 상태로 판단하였다. ${ }^{14}$ 전 치부는 과개교합 상태로 파절된 상악 중절치의 치경부 에 하악 잔존치에 의한 마모와 점막의 압흔을 통해 하악 절치가 상악 절치 구개측 치은열구에 교합되는 Akerly's classification type II로 판단된다. 또한 역전된 윌슨만곡 과 잔존치의 전반적인 마모로 불균일한 교합평면 관찰되 었다(Fig. $3 \mathrm{G}$ ). 경두개방사선영상을 통해 관찰한 과두의 운동은 1 inch 개구 시 전방운동이 크고 $\mathrm{CBCT}$ 영상을 통한 양측 과두의 전두단면에서는 내상방 관절면의 평탄 화(flattening sign)가 관찰되었다.

앞서 언급한 문제목록을 토대로 하악 전치부와 우측 제2대구치는 발치하고 상실부위는 임플란트로 수복하 면서 수직고경의 회복을 위해 소구치부위 기준으로 4 $\mathrm{mm}$ 수직고경을 거상하는 전악수복을 진행하기로 하였 다. 좌측 구치부의 수평피개를 개선하고 불균일한 교합 평면을 개선하여 균일한 교합접촉을 가지도록 진단납형 을 제작하였다(Fig. 5). 수평피개 개선을 위해 상악 전치
부와 구치부는 구개측으로, 하악 구치부는 협측으로 임 플란트를 식립하였고, 6개월 후에 임플란트 2차 수술을 시행하여 치유 지대주를 체결하였다. 상하악 임시보철물 을 제작하기 위해 구강 내 임플란트 수준에서 인상용 코 핑 체결한 후 기성 트레이와 부가중합형 실리콘 인상재 (I-Sil ${ }^{\mathrm{TM}}$ Regular Body \& Light Body, Spident)를 이용하 여 인상을 채득하고, 교합인기재 이용한 중심위 악간관 계기록을 채득하였다. 진단납형을 기준으로 제작된 진 단용 매트릭스를 이용하여 지대치 삭제를 시행하고, 맞 춤형 지대주와 임시치아를 장착하였다 (Fig. 6). 1차 임시 수복물 평가 시 전반적인 교합접촉을 형성하였지만 일부 사면에서 이루어져 불안정하고, 구치부 수평피개와 교합 평면 수정이 부족하며, 특히 수직고경 증가 시 좌측의 수 평피개가 진단 시보다 크게 관찰되었다(Fig. 6B). 하악 운동 기록 시 우측으로 약간의 편위가 있으나 1차 임시 수복물에서 중심위 상태이고 수직고경이 적절함을 확인 하였다(Fig. 7). 이를 토대로 2차 임시수복물을 제작하였 다.

역전된 윌슨만곡 개선하기 위해 하악 설측교두를 추가 삭제하였고 좌측의 수평피개를 개선하기 위해 좌측 하악 구치부 임플란트의 맞춤형 지대주를 재제작하여 2차 임 시수복물을 장착하였다(Fig. 8). 1차 임시수복물에 비해 개선된 수평피개와 교합접촉을 형성할 수 있었고, 3 개월 간 사용 후에도 교합이 안정적으로 유지되는 것을 확인 하여 최종보철물을 제작하기로 하였다.
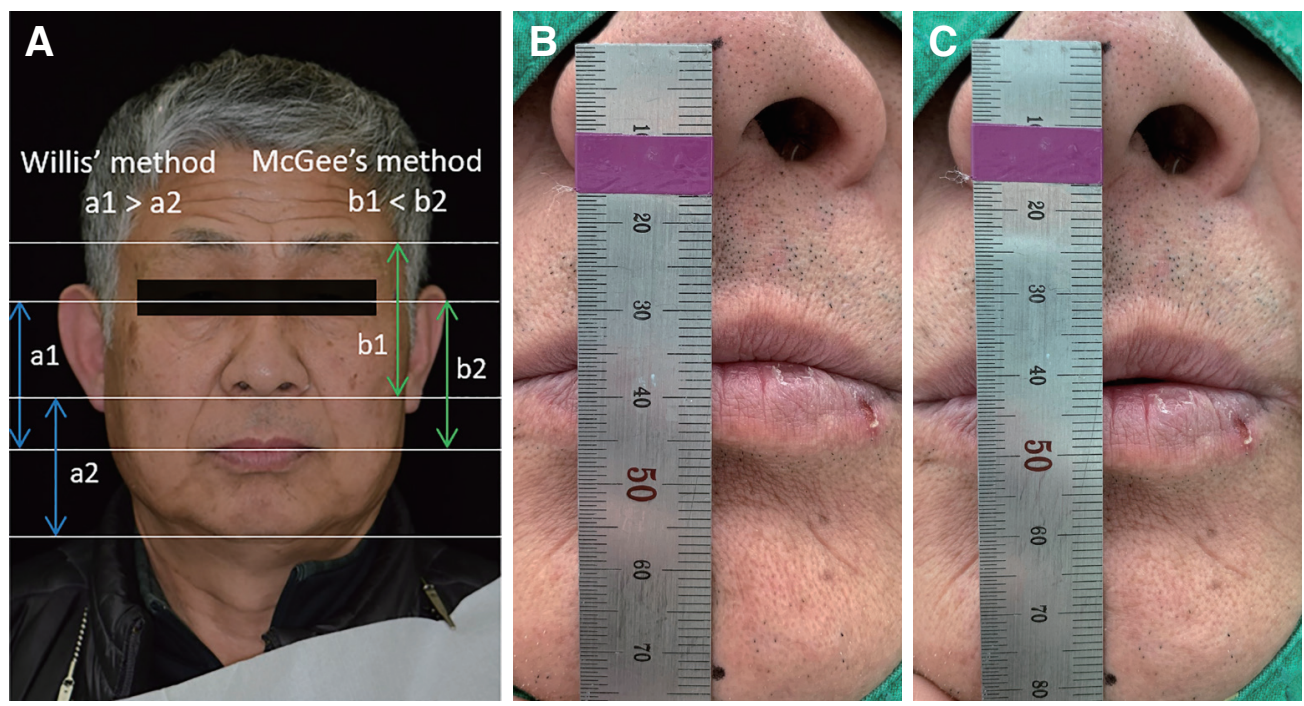

Fig. 4. Vertical dimension evaluation. (A) Facial appearance evaluation, (B) interocclusal rest distance evaluation (maximum intercuspation), (C) interocclusal rest distance evaluation (physiologic rest position). 


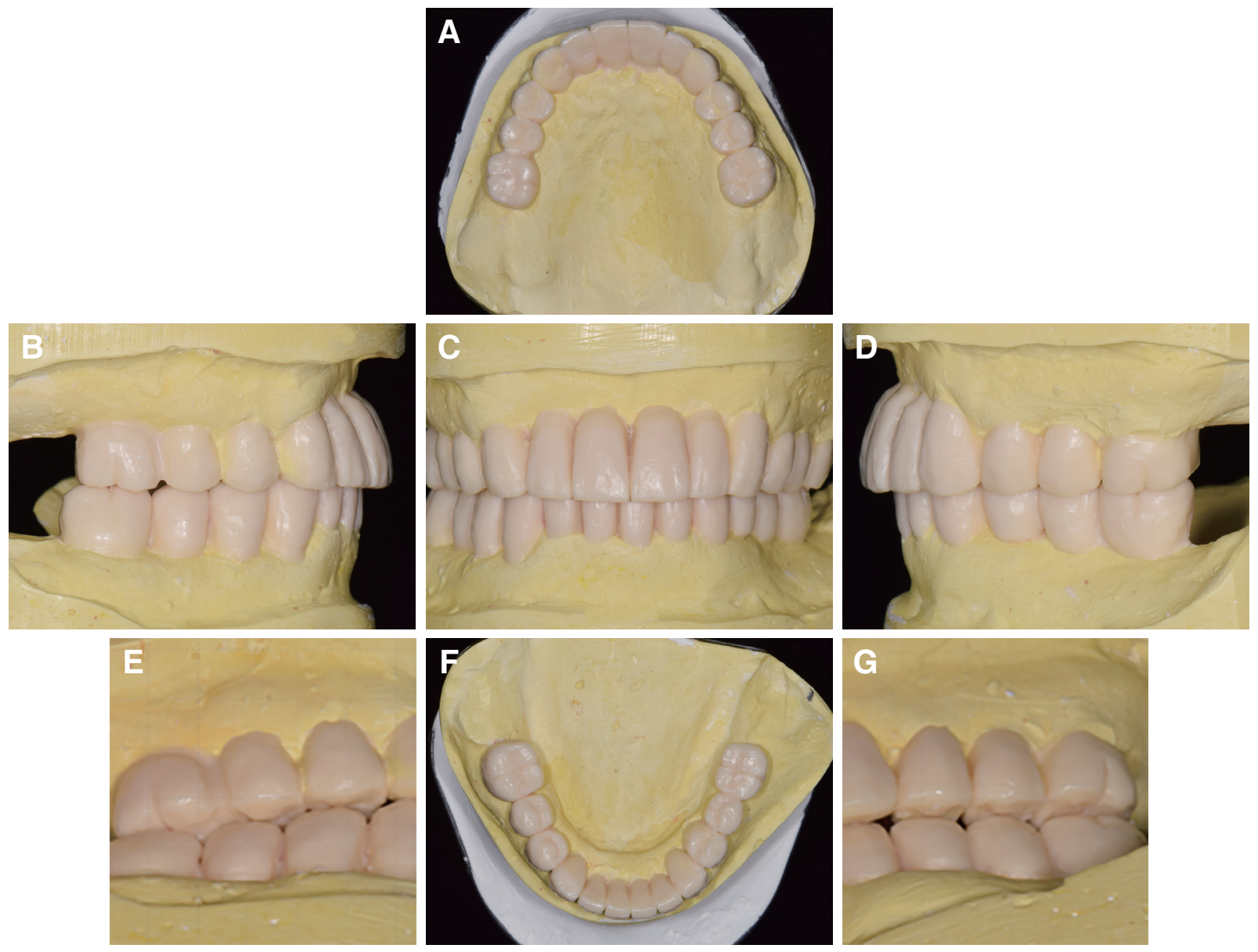

Fig. 5. Diagnostic wax-up. (A) Maxillary occlusal view, (B) Right lateral view, (C) Frontal view, (D) Left lateral view, (E) Right posterior teeth overlap, (F) Mandibular occlusal view, (G) Left posterior teeth overlap.
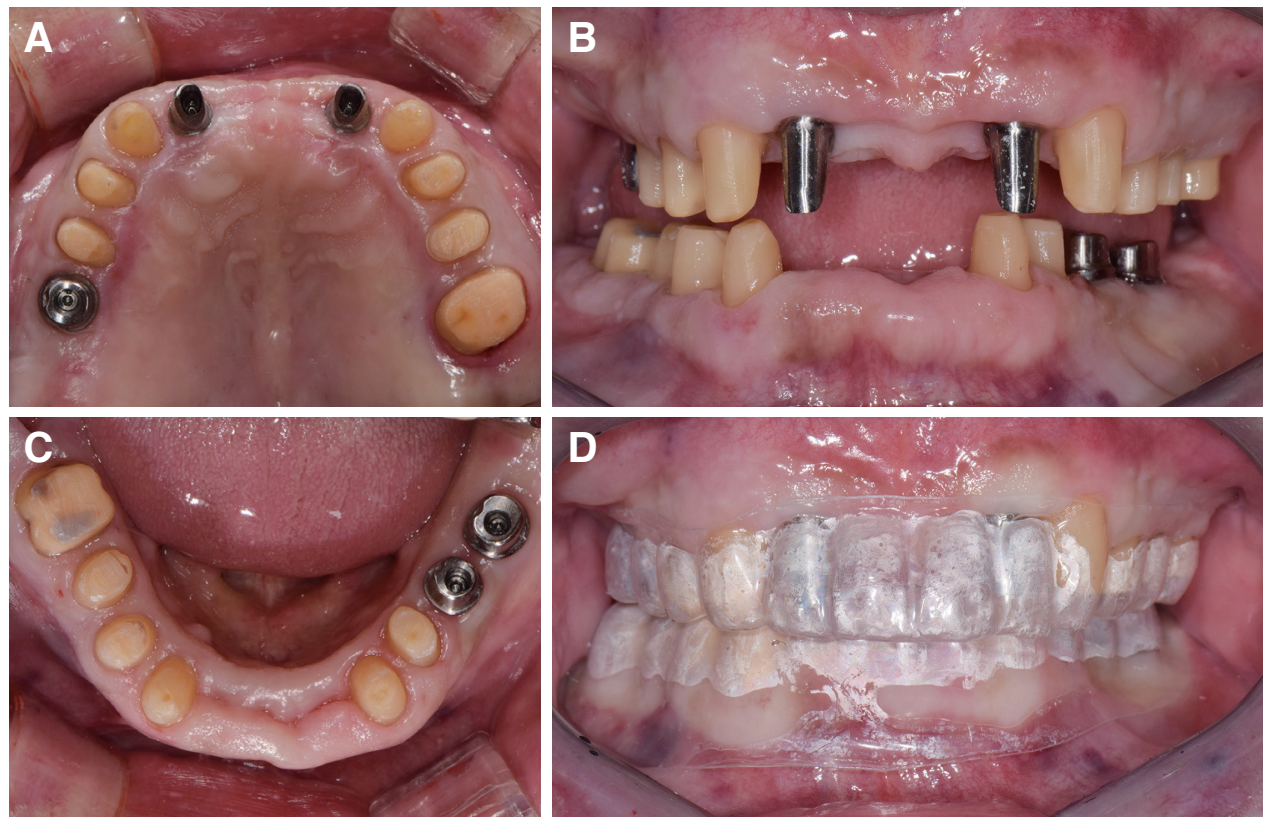

Fig. 6. Teeth preparation procedures. (A) Occlusal view (maxilla), (B) Frontal view with centric occlusion, (C) Occlusal view (mandible), (D) Frontal view of matrix. 

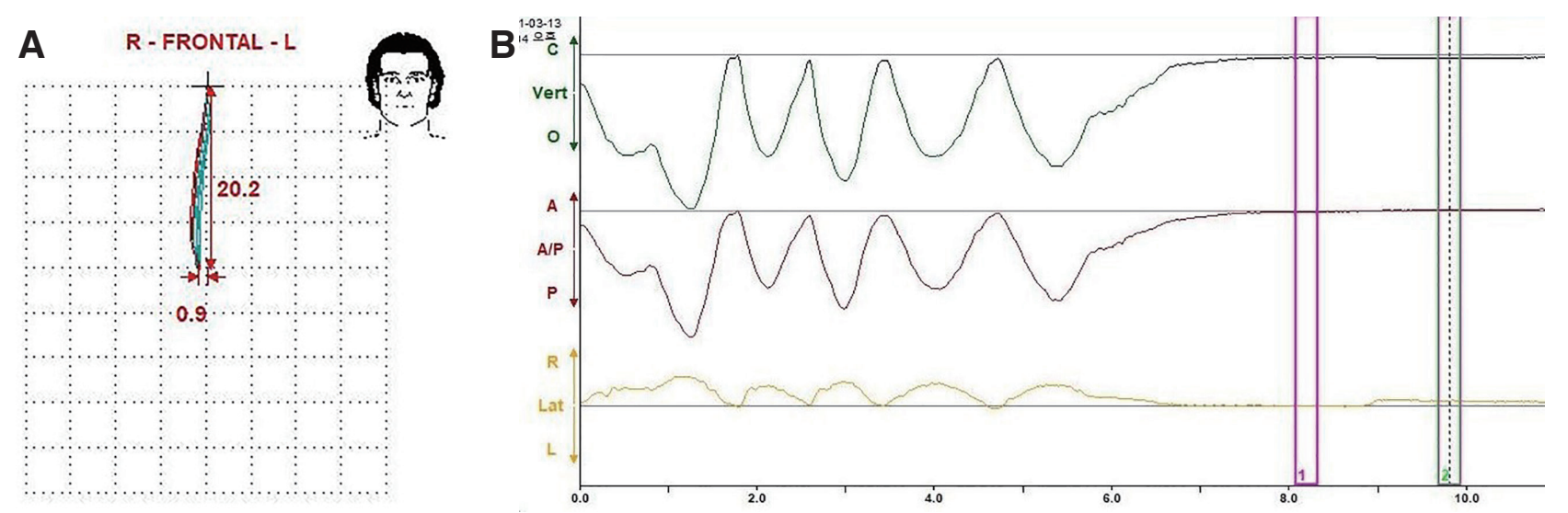

Fig. 7. Mandibular movement registration. (A) Chewing pattern, (B) Centric relation.
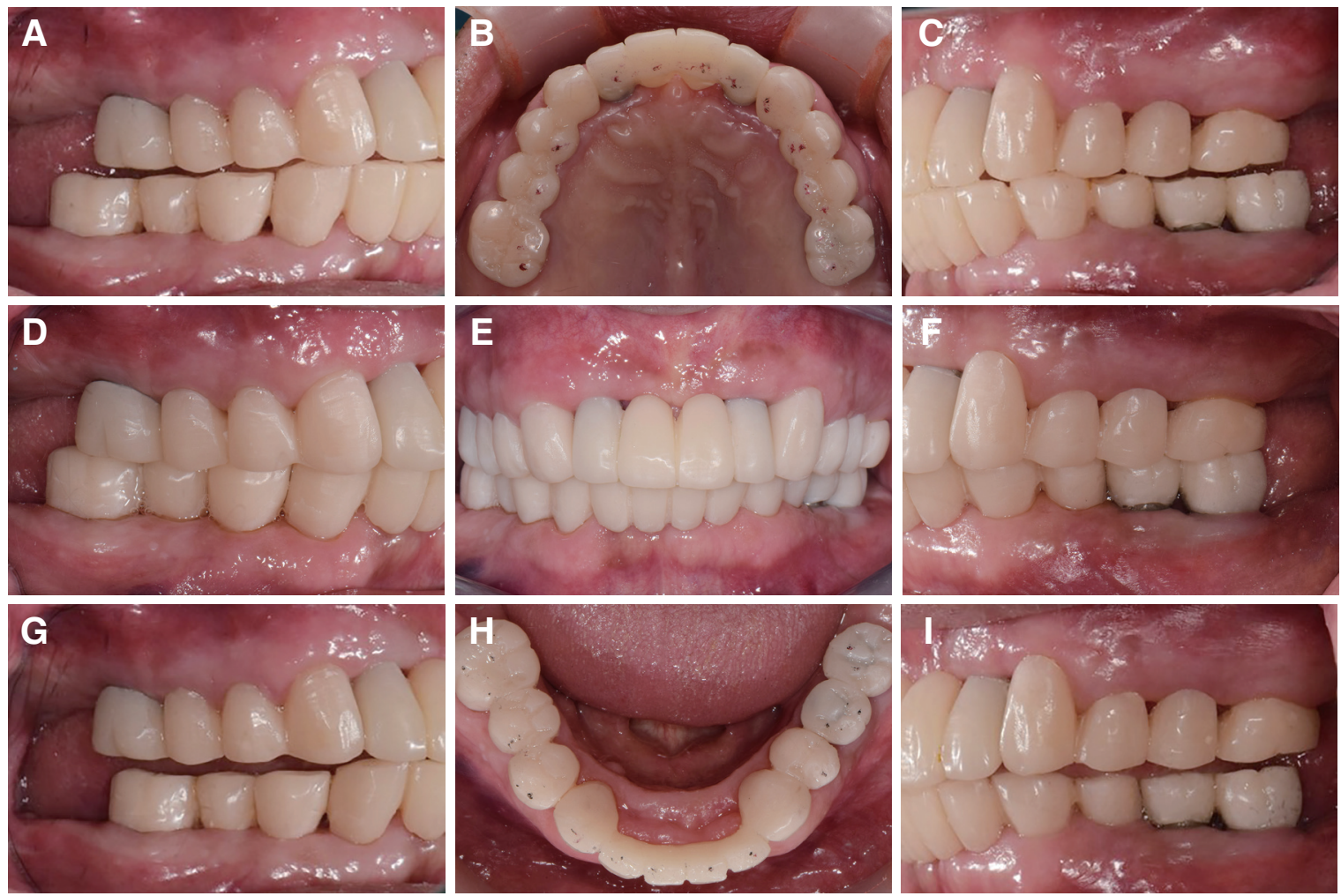

Fig. 8. Intraoral photograph after the placement of $2^{\text {nd }}$ provisional restoration. (A) Working side during right lateral excursion, (B) Maxillary occlusal view, (C) Non-working side during right lateral excursion, (D) Left lateral view at centric occlusion, (E) Frontal view at centric occlusion, (F) Right lateral view at centric occlusion, (G) Non-working side during left lateral excursion, (H) Mandibular occlusal view, (I) Working side during left lateral excursion.

기성 트레이와 부가중합형 실리콘 인상재(Imprint ${ }^{\mathrm{TM}}$ II Garant ${ }^{\mathrm{TM}}$, 3M ESPE, St. Paul, USA)를 이용해 상하 악 최종인상채득을 시행하고, Type IV 초경석고 $(\mathrm{GC}$ Fujirock EP, GC Europe, Leuven, Belgium)를 이용하여 최종모형을 제작하였다. Milled bonnet crown을 제작하 고 이를 이용해 악간관계기록 및 안궁이전하였고, 2차 임
시수복물 장착상태의 모형과 최종모형을 반조절성 교합 기에 교차부착(cross-mounting)한 후 2차 임시수복물 상 태의 전방유도를 재현하기 위해 맞춤전방유도판을 제작 하였다(Fig. 9). 길이에 비해 폭이 좁은 상악 중절치를 보 상하기 위해 측절치를 구개측으로 진단납형을 형성하였 고, 2 차 임시수복물과 동일하게 견치유도 교합방식을 부 
여하였다(Fig. 10). 납형을 토대로 단일구조 지르코니아 전부도재관으로 최종보철물을 제작하였고 임플란트는 SCRP (screw-cemented retained prosthesis)의 형태로 제작하였다(Fig. 11). 완성된 최종보철물은 진료실재부착 (clinical remounting) 과정을 거친 후 교합조정 및 마무
리하여 장착하였다(Fig. 12).

최종보철물 장착 후 구외 안모 관찰 시 상순의 지지와 하안모의 길이가 개선되었고(Fig. 13), 악궁 크기의 부조 화가 개선되었으며(Fig. 14), 수직고경의 증가 후에도 하 악 과두의 위치가 안정적으로 유지됨을 확인하였다.
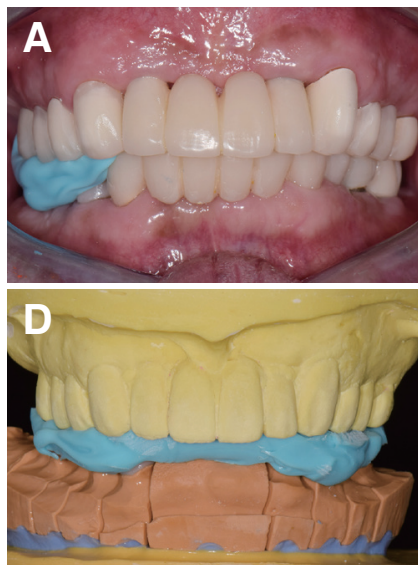
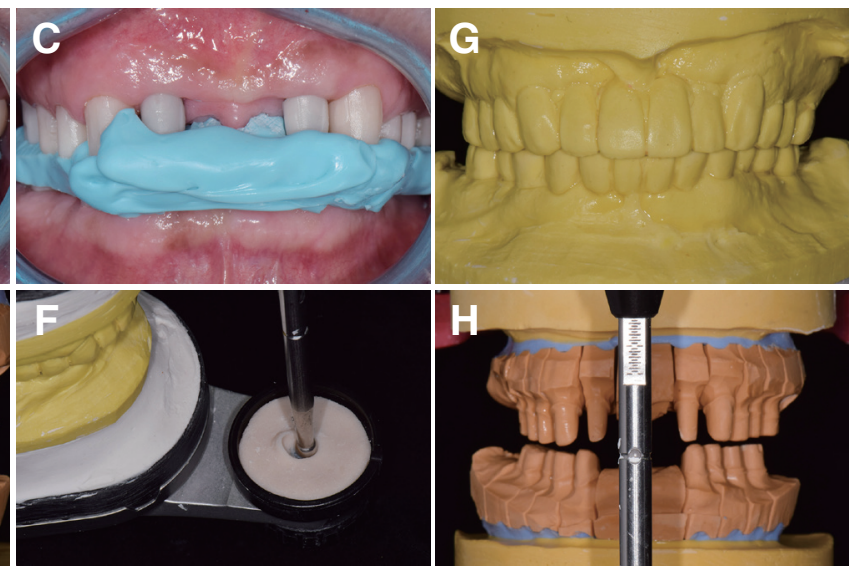

Fig. 9. Cross-mounting procedure. (A - C) Interocclusal relationship registrations using $2^{\text {nd }}$ provisional restorations and milled bonnet crown, (D- F) Cross-mounting of master cast with $2^{\text {nd }}$ provisional restoration cast, (G) Anterior guide table, (H) Mounted mast cast.
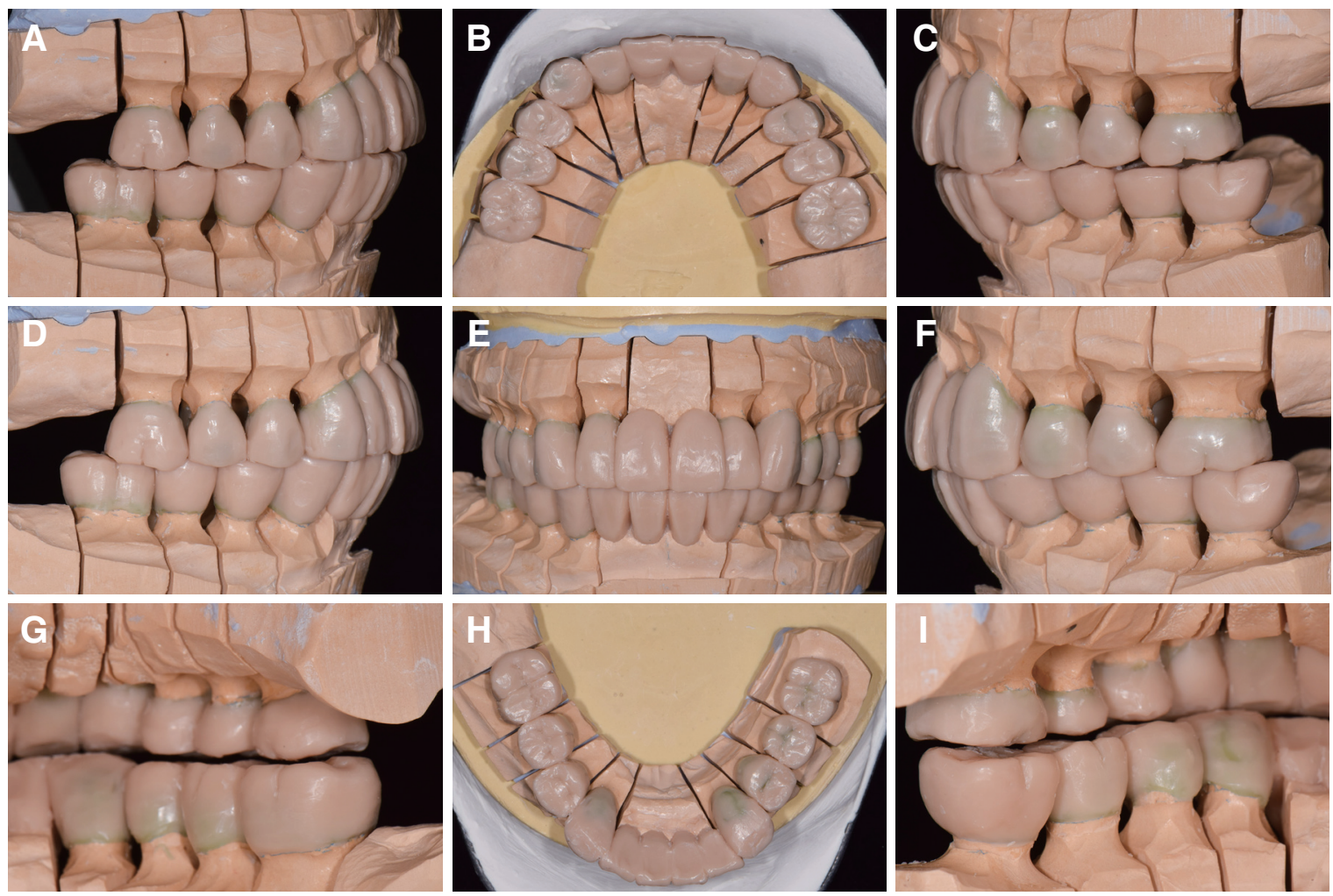

Fig. 10. Wax-up pattern for definite prosthesis. (A) Working side during right lateral excursion, (B) Maxillary occlusal view, (C) Non-working side during right lateral excursion, (D) Left lateral view at centric occlusion, (E) Frontal view at centric occlusion, (F) Right lateral view at centric occlusion, (G) Non-working side during left lateral excursion, (H) Mandibular occlusal view, (I) Working side during left lateral excursion. 

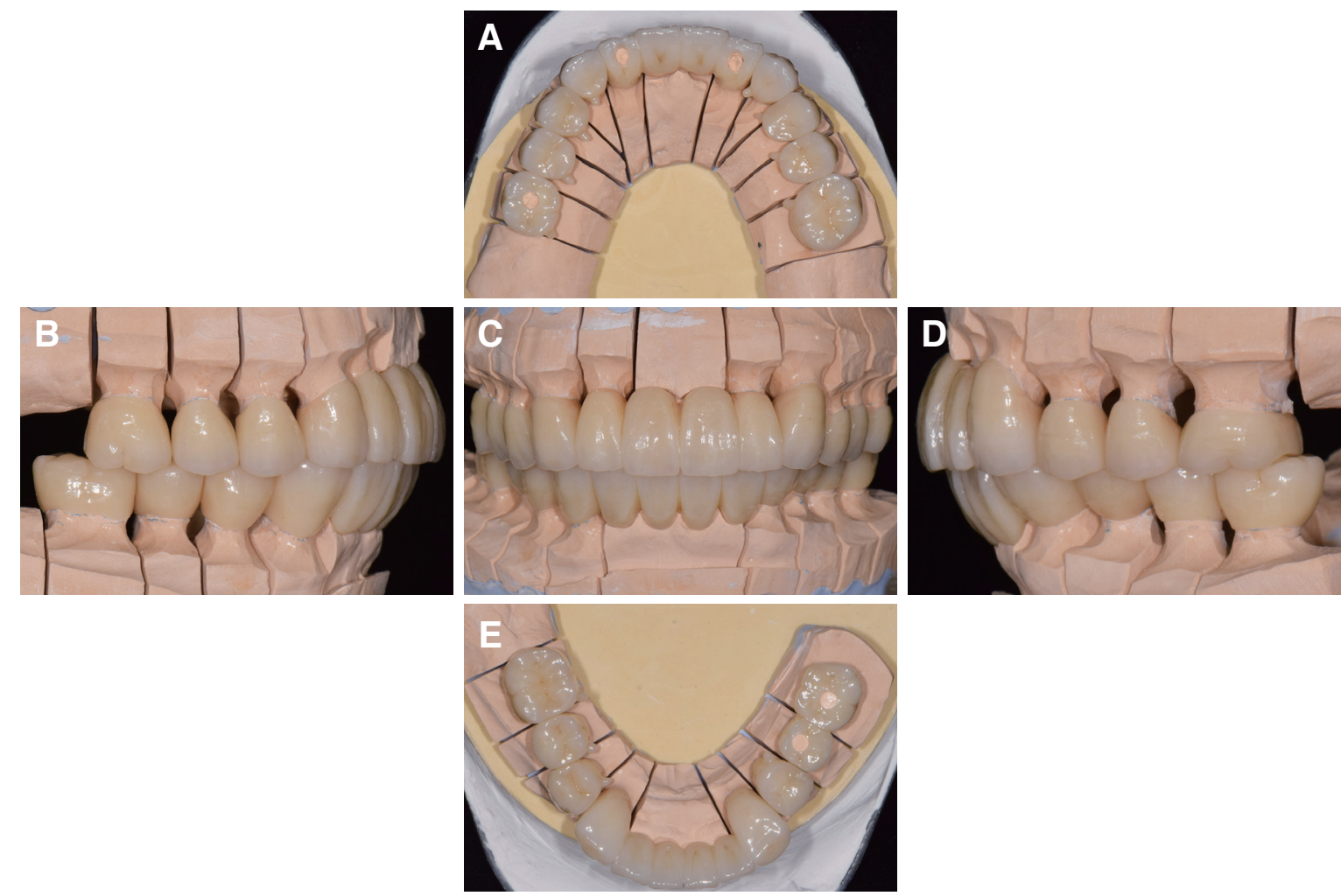

Fig. 11. Definitive prosthesis on master cast. (A) Maxillary occlusal view, (B) Right lateral view, (C) Frontal view, (D) Left lateral view, (E) Mandibular occlusal view.
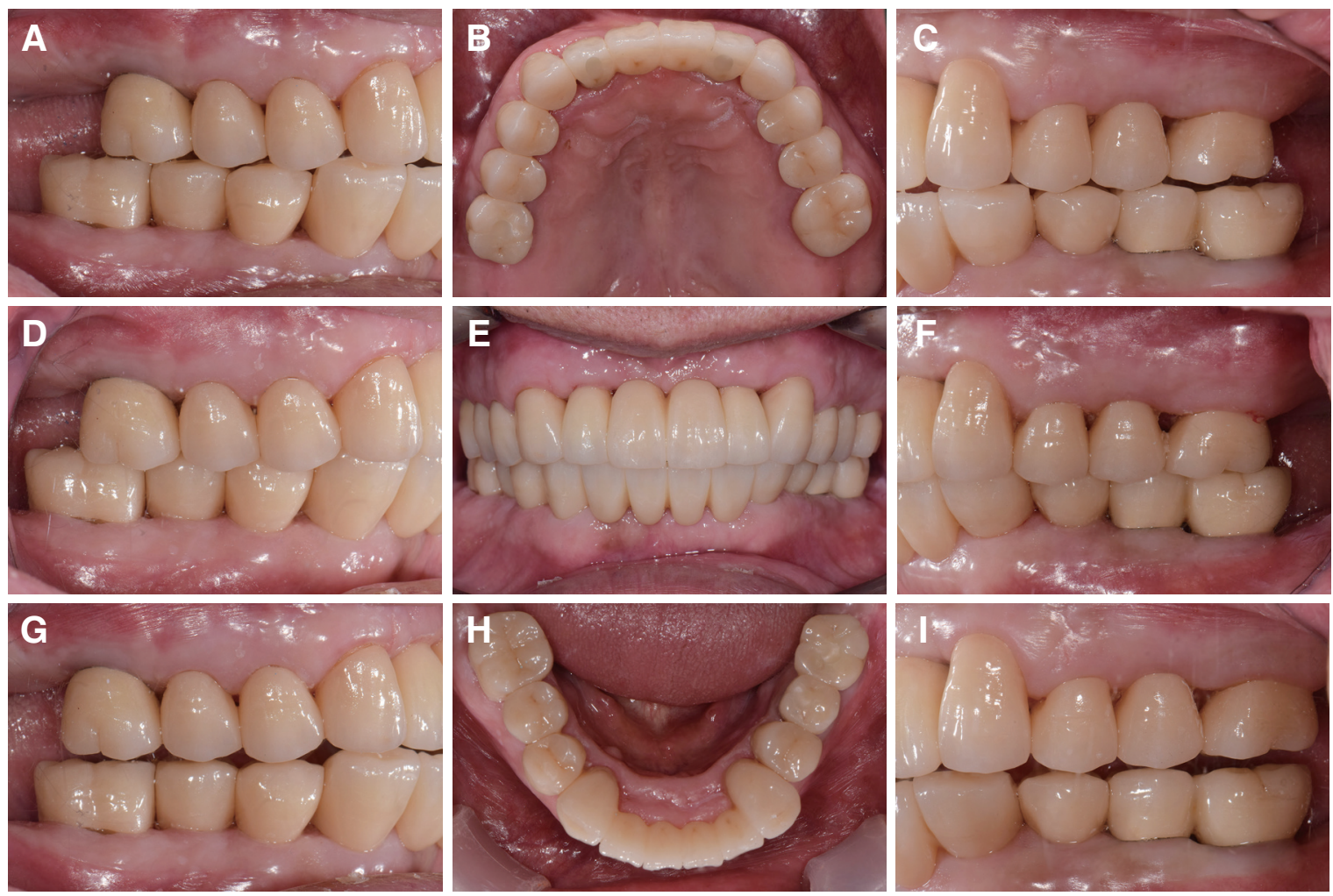

Fig. 12. Intraoral photograph after the placement of definitive prosthesis. (A) Working side during right lateral excursion,

(B) Maxillary occlusal view, (C) Non-working side during right lateral excursion, (D) Left lateral view at centric occlusion, (E) Frontal view at centric occlusion, (F) Right lateral view at centric occlusion, (G) Non-working side during left lateral excursion, (H) Mandibular occlusal view, (I) Working side during left lateral excursion. 

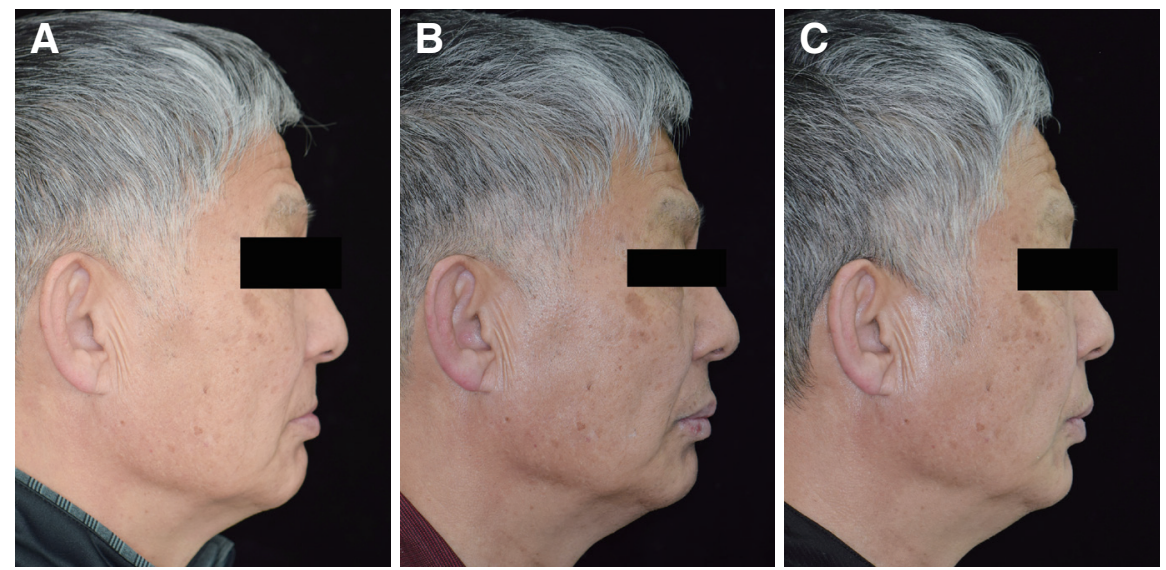

Fig. 13. Facial evaluation at lateral view. (A) Before treatment, (B) Provisional prosthesis, (C) Definitive prosthesis.

A
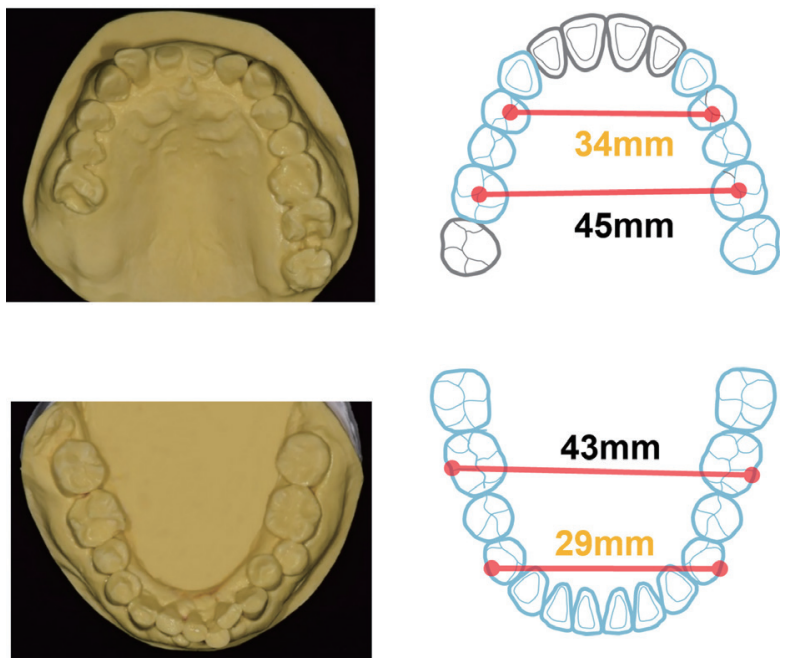

B
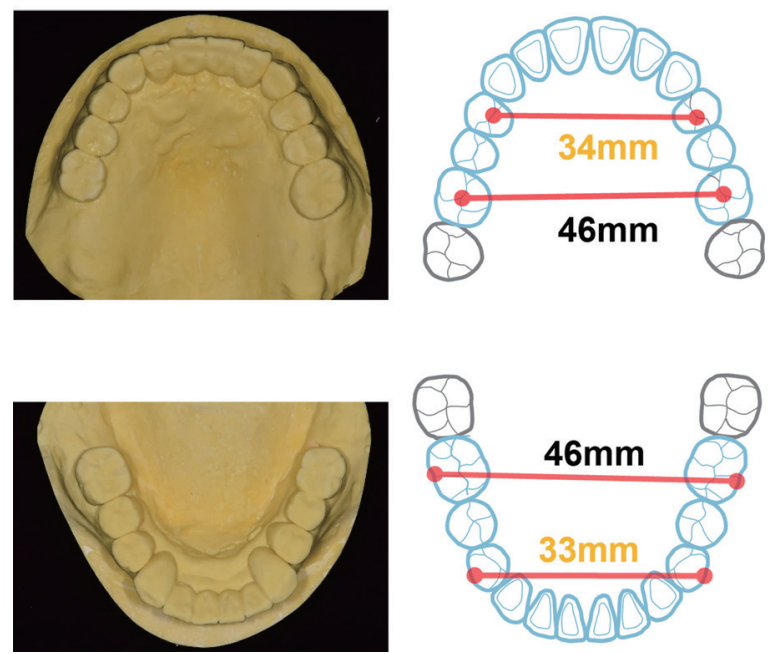

Fig. 14. Inter-dental arch discrepancy. (A) Before treatment, (B) After treatment.

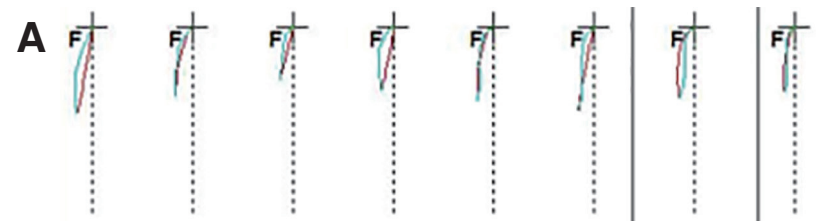

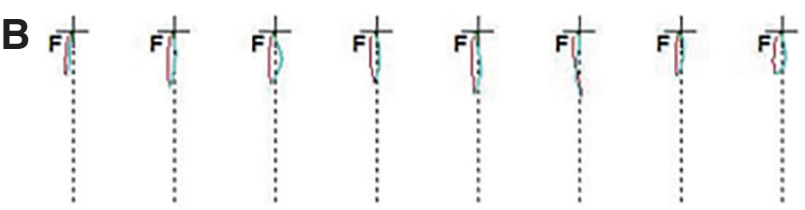

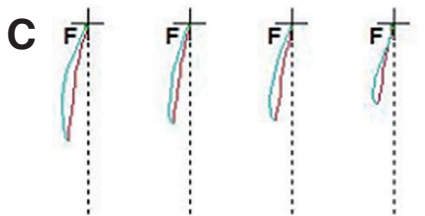

$$
\begin{aligned}
& \text { Fit: }
\end{aligned}
$$
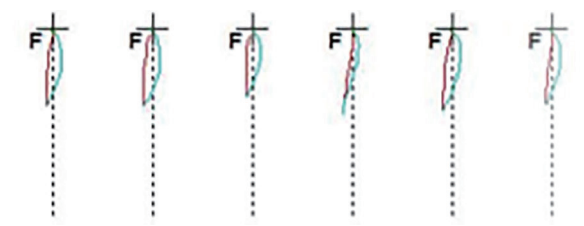

Fig. 15. Chewing pattern analysis. (A) Initial stage of right side, (B) Initial stage of left side, (C) Definitive restoration stage of right side, (D) Definitive restoration stage of left side. 
Table 1. Time measured during chewing cycle and maximum lateral width

\begin{tabular}{lccrc}
\hline & \multicolumn{2}{c}{ Before treatment } & \multicolumn{2}{c}{ After treatment } \\
& Lt. (Scissors) & Rt. (Non-scissors) & Lt. (Scissors) & Rt. (Non-scissors) \\
\hline Opening time & $165.2 \pm 21.2 \mathrm{~ms}$ & $153.8 \pm 18.4 \mathrm{~ms}$ & $175.3 \pm 21.6 \mathrm{~ms}$ & $178.3 \pm 25.6 \mathrm{~ms}$ \\
Closing time & $229.1 \pm 16.3 \mathrm{~ms}$ & $203.7 \pm 14.7 \mathrm{~ms}$ & $184.7 \pm 10.2 \mathrm{~ms}$ & $185.3 \pm 14.9 \mathrm{~ms}$ \\
Occlusal time & $340.7 \pm 11.1 \mathrm{~ms}$ & $320.5 \pm 26.0 \mathrm{~ms}$ & $282.0 \pm 17.7 \mathrm{~ms}$ & $301.7 \pm 20.4 \mathrm{~ms}$ \\
Cycle time & $735.0 \pm 33.1 \mathrm{~ms}$ & $678.0 \pm 31.0 \mathrm{~ms}$ & $642.0 \pm 23.0 \mathrm{~ms}$ & $665.3 \pm 28.7 \mathrm{~ms}$ \\
Max. lateral width & $1.3 \pm 0.4 \mathrm{~mm}$ & $1.9 \pm 0.3 \mathrm{~mm}$ & $2.8 \pm 0.5 \mathrm{~mm}$ & $2.5 \pm 0.4 \mathrm{~mm}$ \\
\hline
\end{tabular}
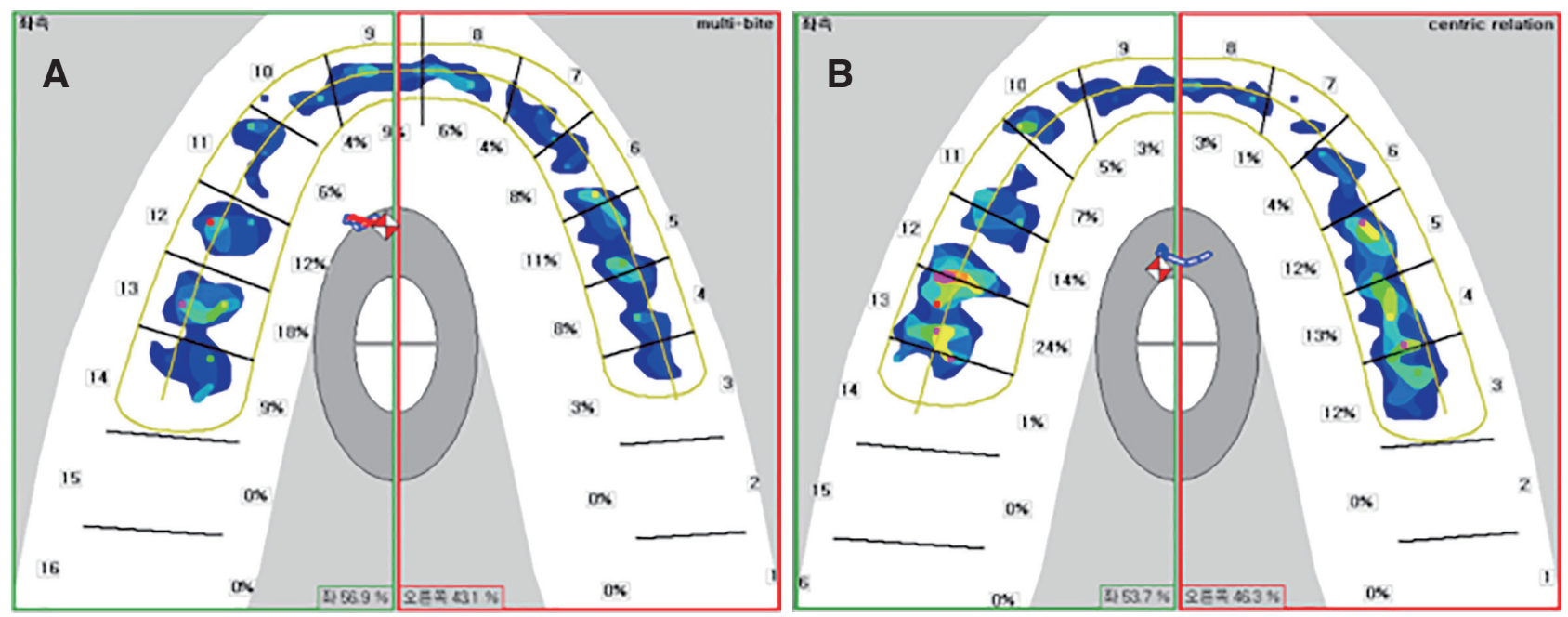

Fig. 16. T-scan (T-scan III, Tekscan Inc., Boston, USA) examination at Maximal Intercuspal Position (MICP). (A) Immediately after definitive restoration, (B) 3 months follow-up after definitive restoration.

\section{고찰}

본 증례는 불안정한 교합접촉과 교합평면의 붕괴로 상 하악 치열궁의 크기 부조화를 보이고, 구치부의 지지상 실과 더불어 좌측 구치부 가위교합 및 전치부 과개교합 을 보이며 수직고경의 상실을 보이는 상태였다. 구치부 가 가위교합인 경우 측방운동이 제한되고 느리며 수직적 인 저작양상(chopping pattern)의 하악 운동을 하게 된 다. ${ }^{11}$ 또한 정상보다 교합면적이 적고 저작 효율이 떨어지 기 때문에 정상교합을 갖는 부위로 선호저작을 하게 된 다. ${ }^{11}$ 본 증례의 경우에서도 치료 전 하악 운동 검사 시 정 상 범위의 수직적인 하악운동 양상을 갖지만 교차교합을 갖는 좌측에서 제한된 측방운동과 긴 저작 시간을 갖는 것을 확인하였다(Fig. 15, Table 1). ${ }^{15}$ 그러나 수평피개와 교합접촉을 개선한 후 하악 운동을 다시 측정하였고 초
진 시보다 좌측의 제한된 측방운동이 다소 개선되었지만 여전히 정상 범위를 나타내진 않았으므로 지속적인 유지 관리로 관찰이 필요할 것으로 사료된다.

교합 관계가 불안정하고 전치부 과개교합을 보이는 환 자를 치료할 때의 목표 중 하나는 중심위에서 안정적인 교합접촉을 형성하는 것이다. ${ }^{8}$ 전치부 과개교합이 구치 부 상실과 함께 교합수직고경의 감소에 따른 결과라면 구치부의 교합고경 증가가 바람직한 치료 목표가 될 수 있다. ${ }^{16}$ 다만 교합수직고경을 증가시켰을 때 하악이 후하 방으로 회전하는 것을 고려하여 전치부 교합관계를 계선 할 수 있는지, 또 진단납형 상에서 상악 설면에 하악 전치 절단의 확실한 교합접촉을 부여할 수 있는지, 그리고 전 방 교합관계의 변화에 따른 전치의 각도와 입술지지 및 미소선을 참고하여 기능과 심미가 조화될 수 있도록 전 치의 형태를 결정하는 것이 중요하다. ${ }^{17}$ 
구치부 지지상실로 인한 상실된 구치부 수복공간을 회 복시키기 위해서는 교합수직고경의 증가를 고려할 수 있 지만 교합수직고경을 증가하게 되면 수평피개가 커지기 때문에 본 증례와 같이 상하악 치열궁 크기의 부조화를 갖는 경우 교정을 동반한 보철치료가 이상적이다. ${ }^{11,16}$ 하 지만 전반적인 치주염을 가진 고연령의 환자를 대상으 로 교정치료를 할 경우 치아 이동의 속도가 느리고 치아 의 수평이동보다 경사이동이 유발되기 때문에, 장기간의 치료 기간이 예상되며 교정치료의 예후를 예측하기 어려 웠다. ${ }^{18}$ 따라서 교정치료는 적합하지 않을 것으로 판단하 였고 진단납형 형성 시 보철치료만으로도 상하악 치열궁 크기의 부조화와 교합수직고경 증가에 따른 전치부 및 구치부의 수평피개 증가가 보상이 될 것으로 예상하였다

(Fig. 5).

그럼에도 불구하고 1차 임시수복물 상태에서는 구치 부 수평피개와 교합평면의 수정이 부족하였는데, 이는 교합재로 채득한 악간관계기록의 오류가 원인으로 생각 된다. 본 증례의 경우 Angle Class II 악간관계를 가지면 서 불안정한 교합접촉으로 인해 중심위가 일정하지 않고 우측으로 편위된 하악운동을 가지고 있었다. 따라서 이 러한 악간관계기록의 오류가 반영되고 평균적인 관절운 동을 보이는 반조절성 교합기는 실제 환자의 과두운동과 차이가 있었고 이를 바탕으로 제작된 1차 임시수복물은 실제 구내에서 많은 양의 조정을 필요로 했으며 결과적 으로 구치부의 수평피개가 진단 시 보다 크게 나타나게 되었다. 따라서 2 차 임시수복물은 이를 바탕으로 지대치 를 수정하고 구치부 임플란트의 맞춤형 지대주를 재제작 함으로써 수평피개를 개선한 후 장착하였고 구치부를 비 롯한 전치부 모두에 조화로운 교합관계를 형성할 수 있 었다.

교차부착(cross-mounting)은 기공실 과정에서 임시수 복물 상태로 확인한 교합평면을 최종수복물에 복제 및 수정을 가능하게 하여 보철물을 예지성 있게 제작하기 위한 중요한 과정이다. 또한 교차부착은 심미성과 기능 적인 면에서 오류를 최소화하는 데에 도움을 줄 수 있으 며, 상악 중절치만을 수복하는 작은 수복범위의 증례부 터 전악수복과 같이 광범위한 증례까지 효과적으로 쓰일 수 있다. 본 증례에서는 임시수복물 과정을 통해 증가된 교합수직고경과 달라진 교합평면에 대한 환자의 적응도 를 평가했을 때, 별다른 불편감이나 저작기능의 문제가 없음을 확인했다. 따라서 교차부착을 이용하여 2차 임시 수복물 상태의 교합평면 및 악간관계를 최종보철물을 위
한 납형형성에 반영하고 보다 이상적으로 개선할 수 있 었으며 제작 결과 만족스러운 심미적, 기능적 형태를 얻 을 수 있었다.

견치유도교합(canine protected articulation)이란 수 직적, 수평적 피개를 가진 견치가 하악의 편위운동 시 구 치부를 이개시키는 상호보호 형태의 교합관계로 정의된 다. ${ }^{5}$ 편위운동 시 견치가 구치를 이개시키기 때문에 폐구 근의 대부분을 편안하게 하고 악관절이 안정되며 구치 부에서 교모에 의한 마모 또한 방지할 수 있다. ${ }^{8}$ 본 증례 의 환자는 상대적으로 견치가 소구치에 비해 치주적인 지지가 양호한 상태이며, 치주 처치 후 소구치 자체의 예 후는 나쁘지 않을 것으로 예상하였으나 측방 운동으로 부터 받는 힘에 불리할 것으로 예상하였다. Ambard와 Mueninghoff ${ }^{19}$ 는 건전한 견치가 잔존한 환자에서 견치 에 의한 상호보호교합은 구치부의 이개가 교근의 활성을 감소시켜 2급 부정교합의 수복에 있어 선택될 수 있다고 하였다. 이러한 판단을 종합하여 임시수복물 및 최종보 철물을 견치유도교합으로 형성하였고, 환자는 치료기간 및 유지관리기간 동안 편안한 저작기능을 보였다.

본 증례에서 소구치 부위를 수복하기 위한 재료로 심 미성이 우수한 전부도재관을 우선 고려하였다. 하지만 본 환자는 작은 하악각과 발달된 교근으로 강한 저작력 이 예상되었기 때문에 최종보철물은 우수한 기계적 물성 을 가진 재료가 요구되었다. 이와 더불어 전부도재관에 서 흔히 발생하는 chipping의 가능성을 감소시키기 위해 충분한 수복물 두께를 확보하는 것이 필수적인데 이는 진단납형과 임시수복물 과정에서 교합수직고경 증가량 에 대한 보철 수복의 가능성과 환자의 적응도를 평가했 을 때, 구치부에서 전부도재관을 위한 적절한 수복물 두 께를 확보할 수 있었다. 이와 같은 점을 고려하여 파절과 같은 잠재적인 합병증의 가능성이 낮고 심미적으로도 우 수한 재료인 단일구조 지르코니아를 선택하였고 환자는 기능적으로나 심미적으로 매우 만족하였다.

교합수직고경을 증가시키려고 할 때에는 감소된 교합 수직고경의 양을 측정해야 한다. 본 증례의 환자는 교합 안정거리(interocclusal rest distance) 측정 시 $6 \mathrm{~mm}$ 로 나타났으며(Fig. 4B, 4C) 이는 평균치인 $2-4 \mathrm{~mm}$ 보다 큰 수치이다. 치아의 상실과 마모로 인한 수직고경의 상 실을 회복시키는 것에 대해선 다양한 의견이 있다. 환자 의 수직고경을 변화시키는 것은 교합 양식에 영향을 주 게되고, 저작근의 활성과 교합력을 증가시켜 턱관절 장 애와 같은 부작용을 초래할 수 있다는 의견이 있는 반 
면, Turner와 Missirlian ${ }^{14}$ 은 휴식상태에서의 악간 공간 이 교합상태의 악간공간보다 $2 \mathrm{~mm}$ 이상 크면 안전하 게 수직고경을 증가시킬 수 있다고 보고하였으며, Gopi Chander와 Venkat ${ }^{20}$ 는 안정위 수직고경범위 내에서 수직 고경을 증가시키는 것은 수용가능하고 특별한 부작용 없 이 새로운 수직고경으로 재설정될 것이라고 하였다. 따 라서 수직고경의 증가 여부 및 증가량은 신중히 고려되 어야 하고, 수직고경 증가 시에는 임시수복물을 통한 평 가가 필수적이다. Ambard와 Mueninghoff ${ }^{19}$ 는 2급 악간 관계의 환자에서 수직고경을 증가시켜 보철수복을 하는 경우, 교합접촉을 올바르게 형성하면 증가된 수직고경에 서 근육의 적응은 허용할 수 있다고 주장하였다. 본 증례 의 환자는 교합안정거리를 기준으로 2 - $4 \mathrm{~mm}$ 의 범위 내 에서 수직고경의 증가량을 결정해야 하는데, 진단납형을 형성하였을 때 증가량이 $2 \mathrm{~mm}$ 일 경우 교합평면의 개선 이 적절하지 못하였다. 따라서 증가량을 $4 \mathrm{~mm}$ 로 결정하 였고 임시수복물 과정을 통해 안정적인 교합접촉을 형성 한 결과 적절한 수평피개와 교합평면을 확인하였다. 본 환자는 증가된 수직고경에 불편감 없이 잘 적응하였기에 최종 수복물에 임시수복물의 형태를 반영하였으며, 유지 관리기간 동안에도 교합접촉이 유지되는 것을 확인하였 다(Fig. 16).

\section{결론}

불안정한 교합접촉 및 교합평면의 붕괴로 인하여 치열 궁 크기의 부조화를 비롯한 전치부의 과개교합과 구치부 의 가위교합, 그리고 교합수직고경의 감소를 보이는 환 자에서 수직고경을 증가시켜 전악보철수복을 진행하였 다. 임시수복물 과정을 통해 조화로운 교합접촉과 교합 평면을 형성하였고 이를 반영한 최종보철물로 기능과 심 미적으로 만족스러운 결과를 얻을 수 있었다.

\section{ORCID}

Han-Sol Song https://orcid.org/0000-0003-2080-6741

Ye-Jin Lee https://orcid.org/0000-0003-3431-5249

Kyung-Ho Ko https://orcid.org/0000-0002-1260-8844

Yoon-Hyuk Huh https://orcid.org/0000-0003-4072-5199

Lee-La Cho https://orcid.org/0000-0003-3989-2870

Chan-Jin Park https://orcid.org/0000-0003-4734-214X

\section{References}

1. Amsterdam M. Periodontal prosthesis. Twenty-five years in retrospect. Alpha Omegan 1974;67:8-52.

2. Ramfjord SP, Ash MM. Occlusion. WB Saunders Co; Philadelphia; 1966.

3. Shifman A, Laufer BZ, Chweidan H. Posterior bite collapse-revisited. J Oral Rehabil 1998;25:376-85.

4. Okeson JP. Management of temporomandibular disorders and occlusion. 7th ed. St. Louis; Mosby Elsevier; 2008.

5. The glossary of prosthodontic terms. J Prosthet Dent 2017;117:e1-105.

6. Sicher H, DuBrul EL. Oral Anatomy. 5th. Ed. St. Louis; The C. V. Mosby Company; 1970.

7. Akerly WB. Prosthodontic treatment of traumatic overlap of the anterior teeth. J Prosthet Dent 1977; 38:26-34.

8. Dawson PE. Functional occlusion: From TMJ to smile design. St. Louis; Mosby; 2006.

9. The council of professors of dental universities. Textbook of orthodontics. 3rd ed. Seoul; DaehanNarae Publishing; 2006.

10. Gupta ND, Mahesgwari S, Chaudhari P, Goyal L. A critical review of the management of deep overbite complicated by periodontal diseases. Eur J Gen Dent 2012;1:2-5.

11. Tomonari H, Kubota T, Yagi T, Kuninori T, Kitashima F, Uehara S, Miyawaki S. Posterior scissorsbite: masticatory jaw movement and muscle activity. J Oral Rehabil 2014;41:257-65.

12. Eichner K. Renewed examination of the group classification of partially edentulous arches by Eichner and application advices for studies on morbidity statistics. Stomatol DDR 1990;40:321-5.

13. Willis FM. Features of the face involved in full denture prosthesis. Dent Cosmos 1935;77:851-4.

14. Turner KA, Missirlian DM. Restoration of the extremely worn dentition. J Prosthet Dent 1984;52: 467-74.

15. Proeschel PA. Chewing Patterns in Subjects with Normal Occlusion and With Malocclusions. Semin Orthod 2006;12:138-49.

16. Won S, An K, Park CJ, Cho LR, Huh YH. Rehabilitation of unstable occlusion caused by inter-dental 
arch discrepancy. J Korean Acad Prosthodont 2015;53:377-91.

17. Chae HS, Jeon BS, Lee JJ, Ahn SG, Seo JM. Full mouth rehabilitation in patient with loss of vertical dimension and deep bite due to tooth wear. J Korean Acad Prosthodont 2019;57:405-15.

18. Ong MM, Wang HL. Periodontic and orthodontic treatment in adults. Am J Orthod Dentofacial Orthop 2002;122:420-8.

19. Ambard A, Mueninghoff L. Planning restorative treatment for patients with severe Class II malocclusions. J Prosthet Dent 2002;88:200-7.

20. Gopi Chander N, Venkat R. An appraisal on increasing the occlusal vertical dimension in full occlusal rehabilitation and its outcome. J Indian Prosthodont Soc 2011;11:77-81. 


\section{과개교합과 치열궁부조화 및 수직고경 감소를 가진 환자의 전악수복증례}

송한솔 전공의, 이예진 전공의, 고경호 조교수, 허윤혁 부교수, 조리라 교수, 박찬진* 교수

강릉원주대학교 치과대학 치과보철학교실 및 구강과학연구소

구치부 지지 상실과 같은 치아 결손은 불안정한 교합 관계를 야기하고 중심위나 습관적 폐구위에서 하악의 전방 활주 시 전치부에 과도한 하중을 초래하기 쉬워 교합평면이 붕괴되며 교합수직고경의 감소와 악관절 기능 장애까지 나타날 수 있다. 치열궁 크기의 부조화는 전치부와 구치부에서 수직수평적인 관계의 부조화를 유발하며 이로써 나타나는 전치부의 과개교합과 구치부의 가위교합은 불안정한 교합접촉과 충분하지 못한 교합접촉면적을 야기한다. 본 증례는 이와 같은 문제들이 복합적으로 나타나는 환자로 임시보철물을 이용하여 교합수직고경 증가 및 새롭게 설정한 교합평면에 대한 적 응을 평가하였고, 교차 모형부착을 이용하여 최종보철물에 반영하여 수복하였다. 그 결과 안정적인 교합과 조화로운 수 직수평피개 및 교합평면을 형성하여 기능적, 심미적으로 만족스러운 결과를 얻어 이를 보고하고자 한다.

(구강회복응용과학지 2021;37(3):157-70)

주요어: 과개교합; 치열궁 부조화; 교합수직고경; 완전구강회복술 